\title{
A RESEARCH PROGRAM FOR SMART GOVERNMENT OF SMART CITIES
}

\section{Claude Rochet}

Doutor em Ciências de Gestão pela Universidad de Aix-Marsella - França

Professor Universitário do laboratório de Pesquisa da Inteligência Econômica do Ministério da Economia, Finanças e Indústria.

E-mail: claude.rochet@univ-amu.fr

\section{Juan David Pinzón Correa}

Universidad de Aix-Marsella - França

E-mail: juan.pinzon-correa@etu.univ-amu.fr 


\title{
URBAN LIFECYCLE MANAGEMENT: \\ A RESEARCH PROGRAM FOR SMART GOVERNMENT OF SMART CITIES
}

\begin{abstract}
At date, there is no standardized definition of what a smart city is, in spite many apply to propose a definition that fit with their offer, subsuming the whole of the city in one of its functions (smart grid, smart mobility...).Considering the smart cities as an ecosystem, that is to say a city that has systemic autopoeiticproperties that are more than the sum of its parts, we develop an approach of modeling the smartness of the city. To understand how the city may behave as a sustainable ecosystem, we need a framework to design the interactions of the city subsystems. First we define a smart city as an ecosystem that is more than the sum of its parts, where sustainability is maintained through the interactions of urban functions. Second, we present a methodology to sustain the development over time of this ecosystem: Urban Lifecycle Management. Third, we define the tasks to be carried out by an integrator of the functions that constitute the smart city, we assume public administration has to play this role. Fourth, we present what should be a smart government for the smart city and the new capabilities to be developed.
\end{abstract}




\section{INTRODUCTION}

This paper draws on the experience of working with industrialists and public authorities involved in smart cities projects. There current problem appearing in their practice is the understanding of how a smart city grows and evolves out of a sum of technological devices. Michael Betty's groundbreaking opus The New Science of Cities (2013) defines the challenge, in the line of though of Jane Jacobs and Chris Alexander, as comprehending the city "as systems built mote like organisms than machines", that is to say a network of flows. And if we want the city to be smart, we needto monitor the growth of the city and predicting its evolution with modeling tools up to the age of the digital economy. Consequently, we need to analyze the smart cities dynamics through the lens of complex systems architecture, to envisage which competencies, and specifically public ones, may be updated to take on this task of modeling.

Since the advent of the "death of distance" with the revolution of transportation by the middle of the $\mathrm{XIX}^{\circ}$ century, the appearance of networks of infrastructure technologies and the spread of the telegraph that transformed the government of the city, critical obstacles to the growth of cities were removed. Today digital technologies amplify this move, providing new tools such as smart phones that became a digital Swiss knife that allows inhabitants to be active actors in the city life, communicating and coordinating with each other, using and feeding databases. Doing this, digital technologies may produce the best and the worst. The point is each city contains the DNA of its own destruction. Smart cities digital infrastructure amplifies the possibilities of manifestation of discontent, worsening the gap between have and have-nots. Smart cities incur the risk to become the digital analogue of the Panopticon Jeremy Bentham's prison design (Townsend, 2013). Relying n software and data management, the smart city raises also the issue of reliability, system resilience and data safety and privacy. Therefore, architecting the city as a living system is as well technical as political.

\section{WHAT MAKES A CITY SMART?}

Far as back as 1613, the Napolitano Antonio Serra analyzed the city as the place where activities with the biggest increasing returns take place, with a strong correlation between economics and politics (Serra \& Reinert,, 2011). ). The frescoes of the Siena town

Revista de Gestão e Secretariado-GeSec, São Paulo, v. 7, n. 2, p 01-20,mai./ago. 2016. 
hall by Ambroggio Lorenzetti (1338) depict "the good government" as a dynamic equilibrium between intense economic activities and an active political life that gives the people of citizens the power to rule the city according to the principles of the common good. Contemporary evolutionary economics correlates the evolution of institutions with that of economic activity (Serra \& Reinert,, 2011). This evolutionary process was secured thank to learning feedback loops which duration was generations, the latest learning from the former to design the city in a way to optimize interactions between activities.

The growing complexity of cities and the predominance of top-down urban planning made us forgetful of these lessons from the past. In their analysis of present smart cities initiative, Neirotti \& al. (2013) notice that there is no practice that encompasses all the domains, hard and soft, of the cities. The most covered domains are hard ones: transportation and mobility, natural resources and energy. Government is the domain in which the cities report the lowest number of initiatives. More, in the present smart cities research program, there is an inverse correlation between investment in hard and soft domains, smart government being still the poor relative in smart cities initiatives and cities that have invested in hard domains are not necessarily more livable cities. In fact, two models emerge from Neirotti\& al. survey: one focused on technology (with a strong impetus of technology vendors) and another focused on soft aspects, the hard model being dominant. The problem is there are no vendors for soft domains apart the citizens themselves whereas systemic integration relies on soft domains, mainly taking in account the context and valuing social capital.

\section{WHAT IS AN URBAN ECOSYSTEM?}

A smart city is more than the sum of "smarties" (smart grids, smart buildings, smart computing...) although it is referred to in the absence ofa precise and operational definition of what a smart city is(Lizaroiu \& Roscia, 2012). Several pretenders exist on what a smart city could be (Songdo in Korea, Masdar in Abu Dhabi,...) but they are not cities to live in, they are demonstrators, propelled by big companies (e.g. Cisco in Songdo)who apply a particular technology to the conception of a city. In the literature, the smart city is recently defined as an ecosystem, that is to say a system where the whole is more than the sum of the parts and has auto poetic properties (Neirotti et a., 2013, Batty, 2013).

Revista de Gestão e Secretariado-GeSec, São Paulo, v. 7, n. 2, p 1-20,mai./ago. 2016. 
For the system architect this approach implies:

$\square$ - Defining a perimeter that comprehends all the components that have a critical impact on city life: the city needs to be fed, is to import products that may have been manufactured on a basis that does not necessarily fit with sustainable development requirements (pollution, children work or underpaid workers, carbon emissions...). These costs and environmental impact must be charged to the city balance.

$\square$ - Considering the system as a living system where the behavior of inhabitants determines the sustainability of the ecosystemic properties of the city. The underlying assumptions are material systems in addition to immaterial ones - as history, culture, anthropology and social capital - play their role. A recent trend in the literature on development economics, which is contrary to the fad of mainstream economics that consider all territories alike, put the emphasis on the "smart territory" as an unstructured cluster of tradition, culture, and informal institutions able to shape an innovative milieu (Aydalot, 1986).

Assuming the city is an ecosystem, according to the laws of general system theory (Ashby, 1962)it may be conceived as shown in figure 1:

A) Finality: It has a finality made of strategic vision borne by stakeholders (public and economic actors), people living in the city and sustaining this finality through their activities, and preserves its identity by interactions with its environment. A shared strategic vision answers the questions: What is the reason to exist of the city? What is its role? An existing city doesn't exist in a vacuum, it has an history, its founding fathers which a vison that has evolved along time, although not explicitly formulated, and may have lost this vision, evolving out of control under laws of increasing returns (Bettencourt et al., 2007). Sometimes it has lost this finality, as in the case of cities base on a specific economic activity, e.g. Detroit or the Russian monocities. Beyond its specific finality, a city today shares a set of challenges related to climate change, economic development and sustainability.

B) Functional tree Structure: This system may be broken down in tree structures of subsystems: the functions needed to perform the ends of the city. These functions belong to hard (material) and soft (immaterial) domains (figure 4). Hard domains include energy, water, waste, transport, environment, buildings, and healthcare infrastructures. Soft domains include 
education, welfare, social capital, public administration, work, civic activity and economy. What makes the city intelligent as learning and evolving system, is the richness (quantity and speed) of connections between branches. We speak of a tree structure in the sense of Herbert Simon's architecture of complex systems (1969) where the designer connects the subsystems to make the system as a whole emerge according to the aim it pursues. In his seminal paper "a city is not a tree" (1965) Christopher Alexander, an architect initially trained as mathematician and Professor at Berkeley, criticized the conception of the urban planning movement in America, considering it as a "fight against complexity", with no connections between branches. Modern cities conceived for cars, compared to ancient cities, offer a very poor web of connections.

C) Patterns: Alexander formalized his idea of the city conceived as a rich overlapping of building blocks in his 1979 book A pattern language. This insight of considering the whole as a combination of modular and reusable building patterns (referring to problems, structures, objects and events), lingered on the margins of cities architecture but has had an enormous influence in the development of object oriented architecture in software design. Architecture patterns canincorporate practices that have proven successful in the past. This importance of patterns is today recognized in system design with Pattern Based Systems Engineering (PBSE). Patterns provide a common language independent from the underlying technology that may be used at different levels of abstraction and granularity (Broodney, 2014).

D) Components: These functions are operated using tools and artifacts of which end-users are people, specialized workers and ordinary citizens. On one hand, structural and dynamics properties of the patterns are operated thought a finite numbers of visible and technological components. On the other hand, the critical point is that people must not fit the tools but, on the contrary, tools and artifacts will fit to people only if the right societal and institutional conditions are met.

In the context of the third industrial revolution - henceforth called iconomy (Rochet \&Volle, 2015) - computerization and datafication transform cities in "information market places" (Webb et al., 2011) that require strong connection between technology and 
strategy, considering a smart community makes a conscious and agreed-upon decision to deploy technology as a catalyst to solving its social and business needs (Nam \& Pardo, 2011).

Modeling the ecosystem implies answering three questions (Krob, 2009):

-The first question is WHY the city: what is the raison d'être and what are the goals of the city regarding WHO are the stakeholders and WHICH activities will support it? Beginning with this question may avoid the drift towards a techno centered approach relying on technological determinism, one may find in Songdo or Masdar.

- The question "why" is then deployed in questions WHAT: What are the functions the smart city must perform to reach these goals? These functions are designed in processes grouped in subsystems aligned with the goal of the main system.

Figure 1.0: architecting the ecosystem

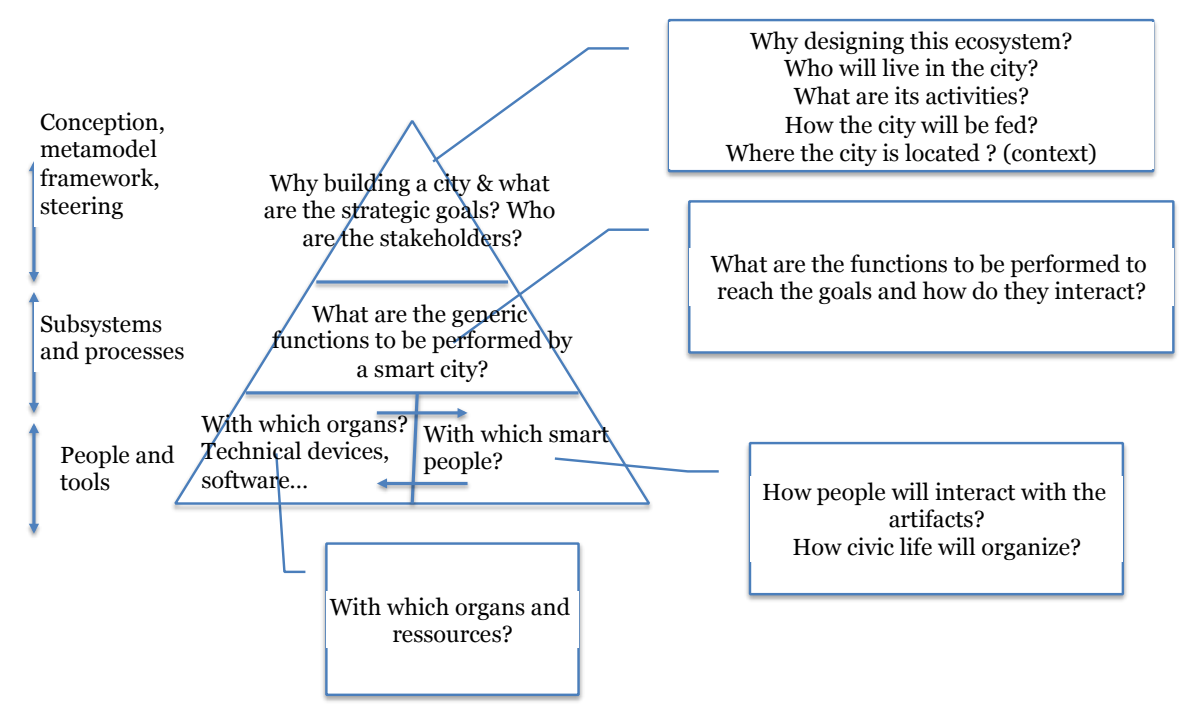

-The third set of questions concern HOW these functions will be processed by technical organs operated by the people who are the city executives and employees, and the city dwellers as end users.

\section{THE GLOBAL FRAMEWORK: URBAN LIFECYCLE MANAGEMENT@}

We assume the rules of complex system modeling and system architecture apply to the city as well as they apply to products through PLM (Product Lifecycle Management) in that case according to a framework we call Urban Lifecycle Management (ULM). The 
difference is a city never dies and must permanently renew its economic and social fabric as well as its infrastructure. An unsmart city will continuously expand according to the laws identified by L. Bettencourtand his colleagues (2007) that reveal increasing returns in infrastructure investment that allow the city to sprawl indefinitely. The complexity will grow out of control, resulting in a city being the sum of heterogeneous boroughs with strong social and economic heterogeneity and spatial dystrophy.

We define ULM first and foremost as a tool to design an ecosystem which will be coherent with the political, social and economic goal people assign to the city according to the principle of sustainable development: stability, waste recycling, low energy consumption, and controlled scalability, but in a way that allows to foresee its evolution and to monitor the transition in different ages of the city. ULM has to counterweight the appeal of technological determinism: in the past, technologies have always dwarfed their intended design and produced a lot of unintended results (Townsend, 2013). ULM has to monitor the life of the smart city alongside its evolution, as represented in figure 2.0.

-Cycle 1: Conception- A city can't be thought out of its historical and cultural context represented by the territory of which the city is the expression. The smart city embarks a strategic vision based on a strategic analysis of the context and material and immaterial assets of the territory (Aydalot, 1986). The smartness of a city profoundly relies on what has been coined as "social intelligence" by prof. StevanDedijer in the years 1970s as the capability to build consensus where each social actor relies on others to create new knowledge. Intelligence doesn't operate in a vacuum but is socially and culturally rooted (Dedijer, 1984).

Revista de Gestão e Secretariado-GeSec, São Paulo, v. 7, n. 2, p 1-20,mai./ago. 2016. 


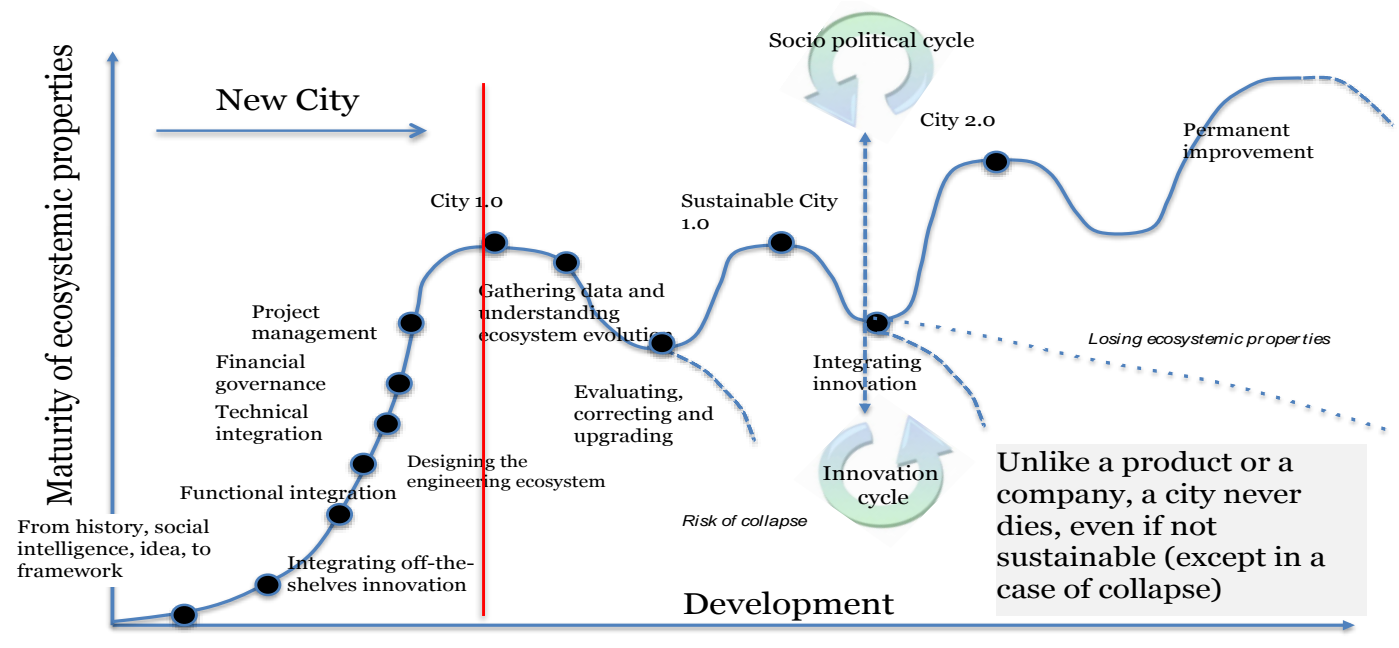

Figure 2.0: Urban Lifecycle Management

- To be livable, the city may not be a prototype: the system architect must focus on the task of integration that needs, to be reliable, to proceed from off-the-shelf components that already have an industrial life and may be considered stable and reliable, in the same way the classical architect does not invent the brick in the same time as he designs the house. This will imply coordination between innovation cycles as we will see further.

- A living city does not exist in a benign environment and is not closed from the wider world. They are dynamic systems that do not return to the equilibrium after a change, either endogenous or exogenous. Thus, cities are not centrally ordered but evolve bottom up as the product of millions of decisions made by individuals and groups, with only occasional top down action. In this "new science of cities" the city conceived as a mechanism is replaced by a living organism (Batty, 2013). Since the main focus of the conceiver is no longer the location of buildings and streets, but interactions between people and activities.

- Cycle 2: Datafication- The process carried out on the principles represented in figure 1 leads to a first release of the city 1.0 in case of a new city. Just as well in a new or old city, we need to understand how the city lives and the unavoidable discrepancies between intended design and real result, an observatory must be implemented that will collect data produced by the city. These data are of two kinds: a) historical data that help understand the path dependency of the city, and b) big data produced by the city daily life to understand how it lives. Corrections are made according to classical principles of quality process management.

Revista de Gestão e Secretariado-GeSec, São Paulo, v. 7, n. 2, p 01-20,mai./ago. 2016. 
- Cycle 3: Innovation- Alongside the lifecycle, exogenous innovation will occur that will need to be endogen zed by the model. For example, Song do in his initial design relied on RFID devices to track city dwellers. Today, smart phones have become the Swiss knife of the city dwellers, rendering the use of RFID devices obsolete. Innovation is ubiquitous in all subsystems of the city. Innovation in smart cars interacts with the architecture of transportation (hard subsystem) as well as in human behavior (soft subsystem). Innovation in the building blocks has very different lifecycles. Coordination will be needed through common frameworks such as projects management office extended to the global smart city's complexity.

Innovation challenges the equilibrium of the smart city in two ways. First, disequilibrium may come from an innovation within a subsystem, which interaction with other subsystems must be tested to avoid unintended consequences, that precisely requires mastering the rules of system integration. Considering a city is an open system, theses rules won't ever be finite and will need to be upgraded permanently. Second, not all innovations are compulsorily good for the city: Civic and political life have to evaluate the consequences of an innovation and to frame it so that it fits with the common good and the sustainability of the city.

- Cycle 4: Continuous improvement- All along its lifecycle, the city may lose its smartness with two undesirable consequences: the city may continue to sprawl on a non-sustainable basis leading to today clog cities. In case of a disruption in its core activity, the city may collapsed as it happened in the past when things had become too complex to be monitored, as studied for past civilizations by archeologist Joseph Tainter (1990). Reducing the size of the city is then the only solution to reduce the complexity. A similar thing appears today in Detroit, a city that has lost its goals and population, leading to the decision of reducing the size of the city as the only means of avoiding bankruptcy of an unmanageable and unproductive city. A similar pattern exists with the Russian monocities (Kirsanova\&Lenkovets, 2014). 


\section{A RESEARCH PROGRAM: THE RATIONALE FOR URBAN LIFECYCLE MANAGEMENT (ULM).}

ULM isbased on the assumptionthat common rules of modeling may be defined applying to different smart cities, consisting in three main principles:

\section{Strategic Analysis}

As represented in figure 1.0 the first task is to define the issues with the stakeholders. The functions needed to reach these issues are then defined (figure 3.0), and deployed in organs and specific competencies and resources.

\section{Inventorying the Building Blocks and Patterns}

In spite we may define general rule of modeling, the smartness of a city will always be specific to the context, e.g. geographical and climate constraints (a city exposed to tropical floods or earthquake will embark functions that a city in a temperate country won't need), economic activity (specialization, search for synergies, position on the commercial routes and worldwide supply chains). The selection of these functions is essential to build a resilient city, e. g. with the climate change new phenomenons occur such as flood, marine submersion, extreme frost, heat waves the city was not prepared for. New building blocks will be needed while new building blocks will be offered by technological innovation.

Nevertheless, common functions will exist in every city and their organization may proceed from off-the-shelf patterns.

Revista de Gestão e Secretariado-GeSec, São Paulo, v. 7, n. 2, p 01-20,mai./ago. 2016. 
Figure 3.0: The building blocks

Issues
- Defining "smartness" and
"sustainability"
- Wealth creation
- Finance and taxes
- Controlling pollution
- Equilibrium center -
periphery
- Migrations
- Poverty
- Education
- Health
- Crime
- Segregation (social and
spatial)
- Leisure
- Quality of life
- How people interact with
people and artifacts?

\begin{tabular}{l}
\multicolumn{1}{|c|}{ Functions } \\
- Work \\
- Budgeting \\
- Transportation \\
- Feeding \\
- Caring \\
- Protecting \\
- Securing \\
- Housing policy \\
- Education \\
- Leisure \\
- Social benefits \\
- Health care system \\
- Migrations control
\end{tabular}

\begin{tabular}{l} 
Resources \\
\hline - Energy \\
- Water \\
- Data \\
- Digital Systems \\
- Traditions \\
- Sociology \\
- Technologies as enablers \\
and enacters \\
- Culture and traditions \\
- Institutions and public \\
organizations \\
- Process modeling \\
- Software \\
- Tech providers \\
- Open innovation \\
\end{tabular}

Capabilities
- The New Business Models:
- Public
- Private
- Project management
- Institutional arrangements
- The day to day decision
making process in an
evolutionarry perspective
- Empowerment
- Direct democracy
- Government
- Governance
- Project management
- Social innovation
- The state as a system
engineer
- Mastering ULM

\section{Integrating the Ecosystem}

In complex systems dynamics, the behavior of a system as a whole is an emergence, that is to say the property of the system can't be attributed to one function in particular but is the result of interactions between these functions (Heylighen, 1991).

The ancestor of the urban planning movement, Ebenezer Howard, thought of the smart city as an ideal city conceived from scratch as a mix of country and city. His insight was to conceive the city as an interaction between a city with jobs and opportunity but with pollution, and the countryside with fresh air and cheap land but with fewer opportunities, each one acting as magnets attracting and repelling people. He invented a third magnet, the Garden city, which combined the most attractive elements of both city and countryside (Howard, 1902). Garden city was the Songdo of its day (Townsend 2013) that galvanized architects, engineers and social planners in search of a rational and comprehensive approach of building city. Howard's approach was excoriated by Jane Jacobs in his Death and Life of Great American Cities (1961) for not giving room to real life: "He conceived of good planning as a series of static acts; in each case the plan must anticipate all the needed... He was uninterested in the aspects of the city that could not be abstracted to serve his utopia". As Dennis Hardy (1991) put it, Howard's garden cities were a quasi utopia of a perfect city in an imperfect world (while communist and fascist utopias have dreamed of the city as a perfect city in a perfect world). Unable to evolve, the garden city dream, not relying on a global systemic architecture, has degenerated in the banal reality of suburban sprawl. The same risk 
exists today with digital technologies, which could revive the ideal city dream, under the impulse of the big players such as Cisco, IBM, Siemens, GE ... who have interest in a topdown and deterministic approach that reduce smart cities to the adoption of their "intelligent" technology.

A smart city as an auto poetic ecosystem must be designed as an imperfect city in an imperfect world able to reframe itself according to the evolution of its environment. Therefore, integration is not made once and for all but is a permanent process all along the urban lifecycle. A smart integration is made according the ends of the city and must be citizen centered and not techno centered. The "good life" is the basic question of political philosophy since Aristotle. It is an ethical issue that will result from political and strategic debates among the stakeholders. Jane Jacobs (1995) had criticized the utilitarian approach that prevailed in America in the city planning movement.

To avoid this bias system architecture must focus on four points:

a) Soft and hard Subsystems: Today's prototypes of would be smart cities are techno driven but mainly forget the inhabitants. City dwellers have the main role to play since it is their behavior and their use (and more and more the production) of information and technology that make the day to day decisions that render the ecosystem smart or no. Figure 4.0 represent both parts of the ecosystem the soft one, or human subsystem, and the hard one, the group of technical subsystems. Integration of these subsystems obeys different laws: human subsystems are dissipative ones, difficult to model, not obeying physical laws, with important entropy. Reducing their uncertainty relies on the sociology of uses, social consensus based on accepted formal and informal institutions, and a close association of inhabitants to the design of the system, which is a common feature of complex system design. Physical subsystems are conservative ones that can be modeled through the laws of physics with a possibility to reduce entropy, but keeping in mind that the decider in last resort is the city dweller who will use it.

b) Outside/Inside: The urban ecosystem is not reducible to the city itself, with perhaps the exceptions of city-states like Singapore which conceives itself as an "intelligent island" (Loo-Lee Sim et al..2003).A city must be fed and having exchanges with a periphery

Revista de Gestão e Secretariado-GeSec, São Paulo, v. 7, n. 2, p 01-20,mai./ago. 2016. 
which produces goods (services, agriculture, food...) in interaction with the center. The design of a system relies on the definition of its border. According to the laws of requisite variety(Ashby law) the inner complexity of a system must be appropriate to the complexity of its environment. So, the urban ecosystem will have to define three perimeters: the first is the city itself where the synergies and interactions are the stronger and have the most "eco" properties. The second is the periphery: one may refer here to the model defined by Thünen at the beginning of the $\mathrm{XIX}^{\circ}$ century representing the city with a succession of concentric rings going from the highest increasing return activities at the center city to decreasing return activities at the periphery (Schwarz, 2010). The third is the external environment with witch the city exchanges, that is, ina age of a globalized world, the rest of the world: the larger this perimeter, the more the system exchanges. This represents logistic costs that may have a negative impact on pollution and carbon emission that may be reincorporated in the balance of the city to measure its smartness, and the more it is subject to external factors of instability and the lesser the ecosystem is coherent and stable as a Thünen zone ${ }^{1}$.

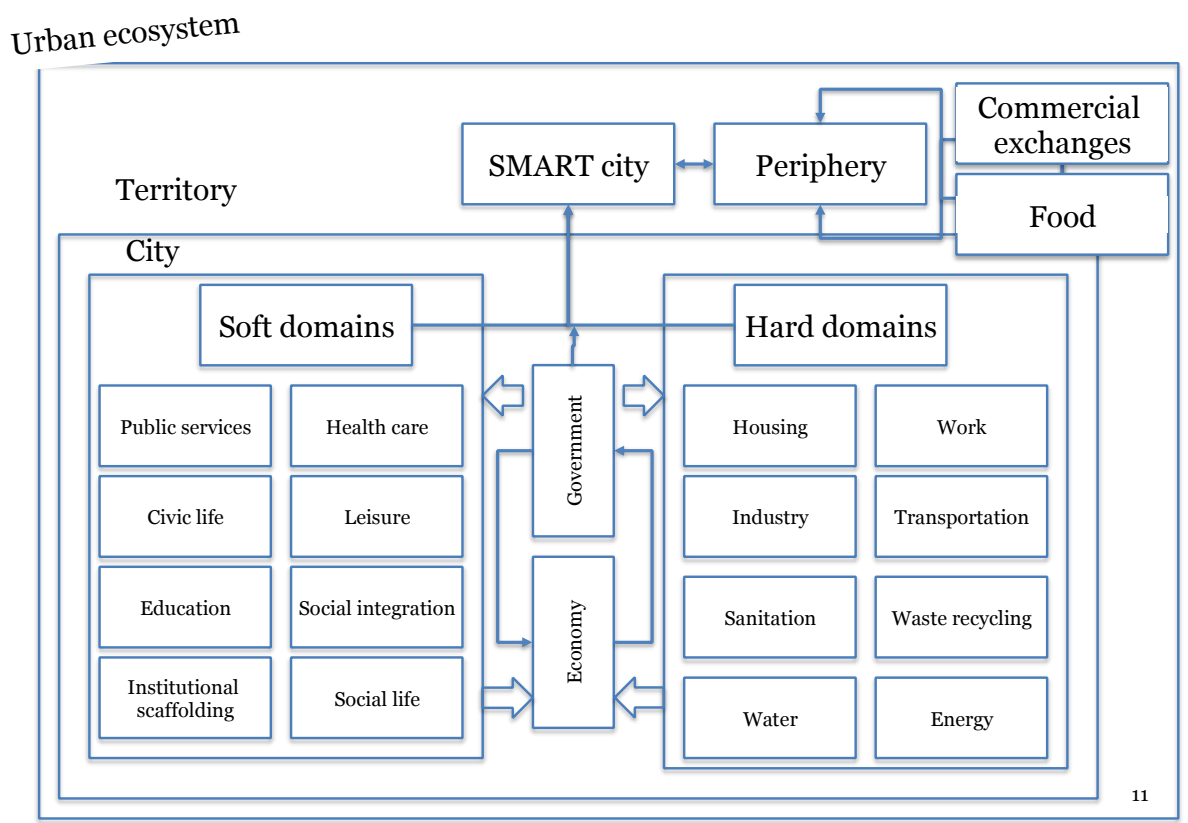

Figure 4: The smart city as an emergence

d) Combining Top Down and Bottom-Up Integration: Each industry has today its model for the integration of its activities. Smart grids, water suppliers, transport operators, IT providers ... have model for systemic integration of their subsystem and to evaluate its

\footnotetext{
${ }^{1}$ We may give as an example the city of Quimper at the heart of the granitic massif of Brittany (France) who choses to import its granite from China.
}

Revista de Gestão e Secretariado-GeSec, São Paulo, v. 7, n. 2, p 1-20,mai./ago. 2016. 
impact on the global functioning of the city. On the other hand, we know that the urban ecosystem being more than the sum of the subsystems we need another approach that starts from the top, that is from the strategic goals of the city deployed in functions as represented in figure 1.0. Where will be the meeting point of these two approaches? Proceeding bottom-up will raise problems of system interoperability, data syntax and semantics, while the top-down approach is more relevant to define strategic issues but will have to integrate all the existing businesses and functions. A possibility is that storing data in common data warehouses and completing it with the exploitation of big data will provide common references. In any case, the answer will proceed from applied research projects in building cities and the developing role of Chief Data Officers in defining common standards.

The other issue for this combination is raised by Alexander: the strategic analysis (point 1 above) must only define "larger scale patterns... to guide the growth and the assembly of smaller patterns" (Alexander et al., 1977: 501). The growth of the smart city is not set from the beginning by a "final goal" but is instead "a process of transformation" continuously repeated so that "the necessary pattern comes into being - not according to some plan, but as a product of a sequence of transformation" (Alexander et al., ibid.).

\section{Smart Government, the Keystone of Smart cities}

Smart cities conceived as ecosystems should provide policy makers with some practical guidelines to integrate soft and hard domains and the evolutionary process of emergence of the future smart city.

Three areas for smart government appear:

Economic Development: In the past, smart cities have been built without central planning (except in the case of Roman cities which reflected the imperial objective of the Roman Empire) but with a clear, although not explicitly formulated, founding purpose: defense, commerce, religion, power, geography... The pattern of the city emerged out of the interactions of key stakeholders: The lord, the barons, the merchants, the shopkeepers, the craftsmen, the bankers and the people. The design of ancient cities made them intelligent since they were ecosystem that sustained and reinvented themselves along time... till the point their capacity to self-reinvent came to an end when the core of their strategic activity

Revista de Gestão e Secretariado-GeSec, São Paulo, v. 7, n. 2, p 01-20,mai./ago. 2016. 
reached a tipping point (e.g. Italian cities after the Renaissance, Russian monocities from the USSR era, Detroit today). The design of these cities obeyed to the real interactions underlying economic life (roads, markets, fairs, harbors, work, industry...) and civic activities (agora, city hall, structure of power). The task of government is to search for the activities that produce the highest increasing returns, no thanks to high technology but to synergies between activities (Reinert, 2012), that will constitute the center of the Thünen zones. The Russian monocities built on a unique industry (coal, oil, cars, aerospace....) linger as long as this industry has a leading role but have very poor capabilities to reinvent itself due to the lack of synergies between different economic activities.

A Vibrant Political Life: With cities emerged political philosophy. The most perspicacious analyst of what makes a city great was undoubtedly Machiavelli who put emphasis on the necessity of the common good : "it is the common good and not private gain that makes cities great", he wrote in his Discourse on Livy. Machiavelli conceived the common good in the Thomas Aquinas' tradition as a whole superior to the sum of its parts. Its systemic equilibrium is permanently challenged by the corruptive forces of fortuna that must be offset by the virtù of the Prince and the dynamism of the vivere politico(Rochet, 2010). Emphasis has been put on the topicality of Machiavelli to understand thesystemic character of public management (Rochet, 2009). The vitality of the system is sustained with permanent interactions within thanks to a vibrant political life that provide a space for controversies. Machiavelli praised the Roman republic for his institution of the tribunate that managed the confrontation between the many of the citizens and the few of the ruling class that allowed the Republic to upgrade his institutions according the principles of the common weal advocated by Cicero. In contemporary complex societies, Elinor and Vincent Oström have developed the concept of polycentric governance that is organizing governance on one hand on a vertical axis from upper to lower levels of complexities, and on the other hand on an horizontal axis which consists of overlappings between organizations (Oström, 2010). Elinor and Vincent Oström have criticized the excess of rationality that defines strict boundaries within missions and attributions of public organizations, since the reality doesn't know these boundaries and the adaptive character of public systems may be found in their overlaps.

Revista de Gestão e Secretariado-GeSec, São Paulo, v. 7, n. 2, p 1-20,mai./ago. 2016. 
Supporting Open Innovation: The experience of cities opening their database to the public to trigger the development of apps has proved the payoff of bottom-up approaches: in Washington DC, a contest "apps for democracy" challenged the local developers to create software exploiting public resources. For a cost of 50000 US\$ the pay-off was blazingly fast with forty seven apps developed in thirty days, representing an estimated 2 million worth of services, about $4000 \%$ return on the city investment (Townsend 2013).But one should not conclude that bottom-up approaches are the killing solution: theses apps are V 1.0 developed by techies on the basis of a fascination for technologies while the city needs V 7.0 tested and reliable and based on the real needs and problem solving of citizens as end-users not familiar with technology. We rediscover here one of the law of innovation emphasized by Von Hippel (1986): the key role of lead users in the innovation process which is furthermore not a specific aspect of innovation in the digital era but a permanent, although forgotten, feature of the innovation process in the industrial era as reminds us François Caron, a leading academic in history of innovation (Caron, 2010).

In the same manner national innovation systems exist (Freeman, 1995) and provide a framework that gives incentives to cooperation between industry, research and investors to steer their activities toward risk taking innovations, extended public administration could structure an urban innovation system that would structure the innovation process in a way that would guarantee that innovation, research and development of so-called smart apps are focused on the real needs of the city dwellers.

This approach requires a combination between soft and hard domains that can be achieved through complex systems of systems (SoS) architecture (Godfrey, 2013), a new discipline, methodology and competency we coin as urban lifecycle management $\odot$. The newborn concept of extended administration finds here its application in its intention to encompass and to design the global value chain of public administration and its interaction with - and between - all the stakeholders. This implies a sea change in the competencies and business model of public administration. This new field would be carried out through research in action projects building cities as ecosystem tending toward resilience where humans are first to decide for the ends.

Revista de Gestão e Secretariado-GeSec, São Paulo, v. 7, n. 2, p 01-20,mai./ago. 2016. 


\section{REFERENCES}

Alexander, C., Ishikawa, S., \& Silverstein, M. (1977). A pattern language: towns, buildings, construction. Oxford University Press.

Ashby, W. R. (1991). Principles of the self-organizing system. In Facets of Systems Science(pp. 521-536). Springer US.

Aydalot, P. (1986). Présentation de Milieuxinnovateurs en Europe, Ph. Aydalot (éd), GREMI.

Batty, M. (2013). The new science of cities. Mit Press.

Caron, F. (2010). La dynamique de l'innovation. Gallimard.

Webb, M., Finighan, R., Buscher, V., Doody, L., Cosgrave, E., Giles, S., ...\& Mulligan, C. (2011). Information marketplaces, the new economics of cities. The Climate Group, Arup, Accenture, Horizon.

Dedijer, S. (1992). Au-delá de L'informatique: L'intelligenceSociale. Lundsuniversitet.

Freeman, C. (1995). The 'National System of Innovation' in historical perspective. Cambridge Journal of economics, 19(1), 5-24.

Gil-Garcia, J. R., Pardo, T. A., \& Nam, T. (2015). What makes a city smart? Identifying core components and proposing an integrative and comprehensive conceptualization. Information Polity, 20(1), 61-87.

Godfrey, P. (2013). Architecting Complex Systems in New Domains and Problems: Making Sense of Complexity and Managing Its Unintended Consequences. In Complex Systems Design \& Management (pp. 41-51). Springer Berlin Heidelberg.

Hardin, G. (1968). The tragedy of the commons. Science, 162(3859), 1243-1248.

Heylighen, F. (1991). Modelling emergence. World Futures: Journal of General Evolution, 32(2-3), 151-166.

Howard, H. (1902). Garden cities of tomorrow. London: Sonnenschein\& Co. Ltd.

Jacobs, J. (1985). Cities and the Wealth of Nations: Principles of Economic Life. Random House.

Kirsanova, N. Y., \&Lenkovets, O. M. (2014). Solving monocities problem as a basis to improve the quality of life in Russia. Life Sci. J, 11(6), 179-207.

Revista de Gestão e Secretariado-GeSec, São Paulo, v. 7, n. 2, p 1-20,mai./ago. 2016. 
Krob, D. (2009). Elémentsd'architecture des systèmes complexes. In A. Appriou (Ed.), Gestion de la complexitéet de l'informationdans les grands systèmes critiques (p. 179207). CNRS Editions

Lazaroiu, G. C., \&Roscia, M. (2012). Definition methodology for the smart cities model. Energy,47(1), 326-332.

Sim, L. L., Ong, S. E., Agarwal, A., Parsa, A., \&Keivani, R. (2003). Singapore's competitiveness as a global city: Development strategy, institutions and business environment. Cities, 20(2), 115-127.

Neirotti, P., De Marco, A., Cagliano, A. C., Mangano, G., \&Scorrano, F. (2014). Current trends in Smart City initiatives: Some stylised facts. Cities, 38, 25-36.

Ostrom E. (1990). GoverningtheCommons: TheEvolution of InstitutionsforCollectiveAction. Cambridge UniversityPress, NY.

Ostrom, E. (2010). Beyond markets and states: polycentric governance of complex economic systems. Transnational Corporations Review, 2(2), 1-12.

Serra, A., \&Reinert, S. A. (2011). A Short Treatise on the wealth and poverty of nations (1613). Anthem Press.

Rochet, C. (2008). Le biencommuncomme main invisible. Le leg de Machiavel à la gestionpublique. Revue internationale des sciences administratives, 74(3), 529-553.

Rochet, C. (2011). Qu'est-cequ'une bonne décisionpublique. Editions universitaireseuropéennes.

Rochet C. \&Volle M. (2015). L'intelligenceiconomique: les nouveauxmodèlesd'affaire de la 3ème révolutionindustrielle. De BoeckSupérieur.

Schwartz, H. M. (2009). States versus markets: the emergence of a global economy. Palgrave Macmillan.

Simon, H. A. (1969). The sciences of the artificial. Cambridge, MA.

Tainter, J. (1990). The collapse of complex societies. Cambridge University Press.

Nam, T., \& Pardo, T. A. (2011). Conceptualizing smart city with dimensions of technology, people, and institutions. InProceedings of the 12th Annual International Digital Government Research Conference: Digital Government Innovation in Challenging Times (pp. 282-291). ACM.

Von Hippel, E. (1986). Lead users: a source of novel product concepts. Management science,32(7), 791-805.

Revista de Gestão e Secretariado-GeSec, São Paulo, v. 7, n. 2, p 01-20,mai./ago. 2016. 
Bettencourt, L. M., Lobo, J., Helbing, D., Kühnert, C., \& West, G. B. (2007). Growth, innovation, scaling, and the pace of life in cities. Proceedings of the national academy of sciences, 104(17), 7301-7306. 